\title{
Determination of Cell Wall Protein from Selected Feedstuffs and its Relationship with Ruminal Protein Digestibility in Vitro
}

\author{
A. Jayanegara ${ }^{a}, *$, S. P. Dewi ${ }^{b}$, N. Laylli ${ }^{b}$, E. B. Laconi ${ }^{a}$, Nahrowi $^{a}$, \& M. Ridla $^{a}$ \\ ${ }^{a}$ Department of Animal Nutrition and Feed Technology, Faculty of Animal Science, Bogor Agricultural University \\ bUndergraduate Program of Nutrition and Feed Technology, Faculty of Animal Science, \\ Bogor Agricultural University \\ Jalan Agatis, Kampus IPB Darmaga Bogor 16680, Indonesia \\ (Received 19-06-2015; Reviewed 09-07-2015; Accepted 17-02-2016)
}

\begin{abstract}
This study was aimed to analyze neutral detergent insoluble crude protein (NDICP) and acid detergent insoluble crude protein (ADICP) contents of various commonly used forage and concentrate feedstuffs in Indonesia. A number of forages and concentrates, i.e. gliricidia, trichantera, indigofera, calliandra, papaya leaves, cassava leaves, leucaena, rapeseed meal, corn gluten feed, soybean meal, copra meal, palm kernel meal, fish and bone meal and wheat bran were subjected to proximate analysis, cell wall nitrogen determination and in vitro rumen fermentation evaluation. Chemical composition analysis was done in duplicate. The in vitro incubation was conducted in $\mathbf{1 4}$ treatments and 3 replicates by following a randomized complete block design. Variables measured after the incubation were total volatile fatty acid (VFA), ammonia, dry matter digestibility (DMD), organic matter digestibility (OMD) and crude protein digestibility (CPD). Results revealed that among the forages, cassava leaf had the highest proportion of NDICP while corn gluten feed was the highest among the concentrates. Different from that of NDICP, the highest proportion of ADICP was obtained in papaya leaf and copra meal for the forages and concentrates, respectively. Higher proportion of NDICP tended to decrease CPD $(P<0.1)$. Although higher ADICP apparently tended to decrease CPD as well, the relationship was insignificant due to the higher variation of the dependent variable. It was concluded that cell wall protein proportion in feed may be used as an indicator to determine the quality of protein and its utilization in the rumen.
\end{abstract}

Key words: cell wall protein, NDICP, ADICP, rumen, digestibility

\section{ABSTRAK}

Penelitian ini bertujuan untuk menganalisis kandungan neutral detergent insoluble crude protein (NDICP) dan acid detergent insoluble crude protein (ADICP) pada sejumlah bahan pakan hijauan dan konsentrat yang umum digunakan di Indonesia. Bahan pakan berupa glirisidia, trichantera, indigofera, kaliandra, daun pepaya, daun singkong, lamtoro, bungkil rapeseed, corn gluten feed, bungkil kedelai, bungkil kelapa, bungkil inti sawit, tepung ikan dan tulang, dan dedak gandum dianalisis kandungan proksimat, nitrogen dinding sel, dan diinkubasi pada sistem fermentasi rumen secara in vitro. Analisis komposisi kimia dilakukan dalam 2 ulangan. Inkubasi in vitro dilakukan dalam 14 perlakuan dan 3 ulangan berdasarkan rancangan acak kelompok. Peubah yang diamati setelah inkubasi adalah total volatile fatty acid (VFA), amonia, kecernaan bahan kering (KBK), kecernaan bahan organik (KBO), dan kecernaan protein kasar (KPK). Hasil menunjukkan bahwa daun singkong mengandung NDICP tertinggi di antara hijauan, sedangkan corn gluten feed tertinggi di antara konsentrat. Proporsi ADICP tertinggi terdapat pada daun pepaya untuk hijauan dan bungkil kelapa untuk konsentrat. Proporsi NDICP yang semakin tinggi cenderung menurunkan KPK $(P<0,1)$. Meskipun semakin tinggi ADICP juga cenderung menurunkan KPK, hubungannya relatif lemah dikarenakan tingginya variasi pada data KPK. Disimpulkan bahwa kandungan protein dinding sel pakan dapat digunakan sebagai indikator kualitas protein pakan dan penggunaannya di dalam rumen.

Kata kunci: protein dinding sel, NDICP, ADICP, rumen, kecernaan

${ }^{*}$ Corresponding author:

E-mail: anuragaja@apps.ipb.ac.id 


\section{INTRODUCTION}

Protein is a main nutrient required by animals either for maintenance, production and reproduction purposes. Protein is a polymer of various combination of amino acids linked together with peptide bonds. In Indonesia, for many years up to present, the protein value of a feedstuff or ration is expressed as crude protein $(\mathrm{CP})$ content. The value is obtained by measuring its nitrogen content through Kjeldahl or Dumas method and multiplied by a constant value of 6.25 . This is based on the assumption that feed protein contains $16 \%$ of nitrogen (Saez-Plaza et al., 2013). This CP value is also used as a main variable for formulating or balancing ration in ruminant livestock. However, CP does not contain any information on the availability of protein when it is digested and utilized by the livestock. High $\mathrm{CP}$ content in a feed does not always related to a high animal performance or productivity due to the difference in protein digestion and utilization in the digestive tract of the animal (Das et al., 2014). In fact, part of feed $\mathrm{CP}$ is degraded by the rumen microbes and transformed into microbial protein. Other part is not degraded by the microbes and directly by-pass to lower intestine which later can be degraded by proteolytic enzymes. Further, the rate of protein degradation in the rumen may vary and can be divided into rapidly, intermediately and slowly degradable fractions (Edmunds et al., 2012). Thus there is a need to consider digestion and utilization characteristics of a feed protein in order to achieve a more precise feed formulation so that it is closely related to animal performance.

Not all CP in a feed can be digested and utilized by livestock. Although the majority of protein is located in the cytoplasm of a plant cell, part of it presents in the cell wall (Tan et al., 2013). This CP fraction is presumed to be less available for microbial and enzymatic digestion, thus contributes to the lower quality of protein. Van Soest et al. (1991) have introduced the analysis of plant cell wall by using neutral detergent and acid detergent solutions to generate neutral detergent fiber (NDF) and acid detergent fiber (ADF), respectively. The residual part of the analysis can be subsequently continued with nitrogen determination to produce a neutral detergent insoluble crude protein (NDICP) and an acid detergent insoluble crude protein (ADICP) (Licitra et al., 1996; Das et al., 2015). Apart from their native presences in plant cell wall, NDICP and ADICP contents are higher in the feed materials dried at high temperatures due to caramelization and browning reactions; the non-enzymatic browning or Maillard reaction causes the condensation of carbohydrate degradation products with protein to form dark-coloured and insoluble polymers (Pelletier et al., 2010; Khan et al., 2015). Determination of such CP fractions may provide important information on the availability of $\mathrm{CP}$ in the digestive tract of livestock. However, to our knowledge, determinations of NDICP and ADICP have not been previously performed in Indonesia.

This study was therefore aimed to analyze the NDICP and ADICP contents of various commonly used forage and concentrate based feedstuffs in Indonesia, i.e. gliricidia, trichantera, indigofera, calliandra, papaya leaf, cassava leaf, leucaena (forages), rapeseed meal, corn gluten feed, soybean meal, copra meal, palm kernel meal, fish and bone meal and wheat bran (concentrates). Further, an in vitro digestibility experiment was performed to assess primarily the ruminal CP digestibility of each feedstuff, and to observe the relationship between such cell wall $\mathrm{CP}$ fractions and the $\mathrm{CP}$ digestibility. It was hypothesized that NDICP and ADICP contents varied among the experimental feedstuffs and that there was a negative correlation between these components and in vitro CP digestibility.

\section{MATERIALS AND METHODS}

\section{Collection and Preparation of Feed Samples}

Feedstuffs used in the present experiment consisted of forages (gliricidia, trichantera, indigofera, calliandra, papaya leaves, cassava leaves and leucaena) and concentrates (rapeseed meal, corn gluten feed, soybean meal, copra meal, palm kernel meal, fish and bone meal and wheat bran). Forage samples were collected from the area of Laboratory of Agrostology, Faculty of Animal Science, Bogor Agricultural University. Concentrates were obtained from commercial suppliers, i.e. PT Indo Feed (corn gluten feed, fish and bone meal and wheat bran) and PT Cheil Jedang Indonesia (rapeseed meal, soybean meal, copra meal and palm kernel meal). Approximately $2 \mathrm{~kg}$ dry matter of each forage species was collected, sun-dried for one day and ground to pass a $2 \mathrm{~mm}$ sieve. Concentrate samples were obtained from commercial suppliers and already in the forms of ground samples. These forage and concentrate samples were subjected to proximate analysis, cell wall nitrogen determination and in vitro rumen fermentation evaluation.

\section{Chemical Composition Determination}

Proximate analysis was performed according to AOAC (2005). Cell wall protein was determined by combining Van Soest analysis (Van Soest et al., 1991) and CP analysis as described by Licitra et al. (2006). Cell wall protein may present either in the NDF residue or in the ADF residue, i.e. NDICP or ADICP, respectively. For NDICP determination, 0.5-1 g of sample was inserted into a beaker glass, added with $100 \mathrm{ml}$ neutral detergent solution and boiled for $60 \mathrm{~h}$. The residue was filtered and dried in an oven at $105^{\circ} \mathrm{C}$. After drying, the sample was continued with CP analysis as above. Similarly, ADICP determination was performed similar to NDICP determination but the solution used was different, i.e. acid detergent solution. The values of NDICP and ADICP were presented proportionally to their corresponding $\mathrm{CP}$ contents to obtain the fractions of nitrogen present in the cell walls. All the proximate and cell wall nitrogen analyses were performed in duplicate. 


\section{In Vitro Rumen Fermentation}

The ground feedstuff samples ( $\mathrm{n}=14$ feedstuffs, consisted of 7 forage and 7 concentrate feedstuffs) were evaluated biologically using a two-stage in vitro rumen fermentation technique according to Tilley \& Terry (1963). Rumen fluid was collected from two fistulated Ongole crossbred beef cattle located at LIPI Cibinong, Bogor with approximately equal proportion from each; it was taken manually from the fistula before morning feeding, put into a warm thermos, and immediately brought to the laboratory for subsequent measurement. The in vitro incubations were done in three consecutive runs ( $n=3$ replicates) at different days in which each replicate was represented by two incubation tubes (duplo). Fermentation fluid at $4 \mathrm{~h}$ incubation period was sampled for total volatile fatty acid (VFA) and ammonia $\left(\mathrm{NH}_{3}\right)$ concentration analyses according to steam distillation and Conway micro-diffusion methods, respectively (General Laboratory Procedures, 1966).

\section{Data Analysis}

Data were analyzed by analysis of variance (ANOVA) based on a completely randomized block design. When the ANOVA result showed $\mathrm{P}<0.05$ for a particular parameter, a post-hoc test namely Duncan's multiple range test was applied to the data. The relationship between NDICP or ADICP in feedstuffs and in vitro $\mathrm{CP}$ digestibility was assessed by using a regression analysis. All statistical analyses were performed by employing SPSS software version 20.

\section{RESULTS}

All forage and concentrate feedstuffs in this study generally contained high levels of CP, i.e. above $20 \%$ DM although some feedstuffs such as leucaena, corn gluten feed, palm kernel meal and wheat bran contained less (Table 1). Among the forages, cassava leaf contained the highest amount of CP (above 30\% DM) and followed by indigofera whereas soybean meal was the highest $\mathrm{CP}$ among the concentrates. Palm kernel meal and copra meal contained the highest CF among the feedstuffs. Generally EE contents of the feedstuffs were low except papaya leaf, copra meal and palm kernel meal which were above 5\% DM. Almost half of fish and bone meal consisted of ash. The contents of NDICP and ADICP varied among the feedstuffs (Table 2). Among the forages, cassava leaf had the highest proportion of NDICP to $\mathrm{CP}$ while corn gluten feed was the highest among the concentrates. Different from that of NDICP, the highest proportion of ADICP was obtained in papaya leaf and copra meal for the forages and concentrates, respectively.

The in vitro rumen fermentation profiles revealed that total VFA production did not differ among the feedstuffs; all feedstuffs produced total VFA above $100 \mathrm{mM}$ after $4 \mathrm{~h}$ of incubation (Table 3). There were feedstuffs producing ammonia above $10 \mathrm{mM}$, i.e. trichantera, indigofera, papaya leaf and fish and bone meal. Within the forages, papaya leaf had the highest DMD and signifi- cantly higher than those of the others $(P<0.05)$, followed by indigofera and trichantera. Among the concentrates, the highest DMD was observed in soybean meal. The OMD showed similar pattern with DMD; the highest OMD for forages and concentrates were papaya leaf and soybean meal, respectively. Most of the proteins in the feedstuffs were highly digestible, i.e. above $70 \%$. But there were some feedstuffs had CPD lower than 70\%, i.e. gliricidia, calliandra, leucaena and copra meal. Higher proportion of NDICP to total $\mathrm{CP}$ tended to decrease the $\mathrm{CP}$ digestibility $(\mathrm{P}<0.1$; Figure 1$)$. Although higher

Table 1. Proximate composition of selected forage and concentrate feedstuffs $(\% \mathrm{DM})$

\begin{tabular}{lrrrrr}
\hline \multicolumn{1}{c}{ Feedstuff } & CP & CF & EE & NFE & Ash \\
\hline Forage & & & & & \\
Gliricidia & 20.09 & 12.44 & 2.27 & 60.37 & 4.83 \\
Trichantera & 24.12 & 13.91 & 3.58 & 47.75 & 10.64 \\
Indigofera & 28.33 & 10.31 & 1.85 & 52.07 & 7.44 \\
Calliandra & 23.12 & 16.64 & 3.99 & 47.64 & 8.61 \\
Papaya leaf & 24.03 & 12.31 & 5.87 & 45.45 & 12.34 \\
Cassava leaf & 33.02 & 11.61 & 2.69 & 44.96 & 7.72 \\
Leucaena & 19.58 & 13.71 & 4.51 & 41.99 & 20.21 \\
Concentrate & & & & & \\
Rapeseed meal & 39.29 & 14.28 & 1.14 & 32.16 & 13.13 \\
Corn gluten feed & 17.65 & 6.50 & 2.17 & 67.69 & 5.99 \\
Soybean meal & 50.42 & 3.87 & 1.86 & 36.78 & 7.07 \\
Copra meal & 23.00 & 20.13 & 8.61 & 41.32 & 6.94 \\
Palm kernel meal & 19.00 & 29.87 & 8.40 & 36.12 & 6.61 \\
Fish and bone meal & 35.69 & 1.04 & 2.33 & 13.79 & 47.15 \\
Wheat bran & 19.15 & 12.85 & 4.26 & 58.78 & 4.96 \\
\hline
\end{tabular}

Note: $\mathrm{DM}=$ dry matter; $\mathrm{CP}=$ crude protein; $\mathrm{CF}=$ crude fiber; $\mathrm{EE}=$ ether extract; NFE= nitrogen free extract.

Table 2. Neutral detergent insoluble crude protein (NDICP) and acid detergent insoluble crude protein (ADICP) content of selected forage and concentrate feedstuffs $(\% \mathrm{CP})$

\begin{tabular}{lcc}
\hline \multicolumn{1}{c}{ Feedstuff } & NDICP & ADICP \\
\hline Forage & & \\
Gliricidia & 62.96 & 28.95 \\
Trichantera & 45.96 & 25.51 \\
Indigofera & 48.49 & 33.83 \\
Calliandra & 39.59 & 28.55 \\
Papaya leaf & 50.89 & 37.53 \\
Cassava leaf & 72.33 & 12.78 \\
Leucaena & 52.53 & 30.04 \\
Concentrate & & \\
Rapeseed meal & 37.53 & 36.28 \\
Corn gluten feed & 69.63 & 9.76 \\
Soybean meal & 29.81 & 15.23 \\
Copra meal & 61.49 & 48.90 \\
Palm kernel meal & 35.21 & 23.76 \\
Fish and bone meal & 57.96 & 22.38 \\
Wheat bran & 46.64 & 12.79 \\
\hline
\end{tabular}

Note: $\mathrm{CP}=$ crude protein. 
Table 3. Fermentation profile and digestibility of selected forage and concentrate feedstuffs

\begin{tabular}{|c|c|c|c|c|c|}
\hline Feedstuff & Total VFA $(\mathrm{mM})$ & $\mathrm{NH}_{3}(\mathrm{mM})$ & $\mathrm{DMD}(\%)$ & OMD (\%) & CPD (\%) \\
\hline \multicolumn{6}{|l|}{ Forage } \\
\hline Gliricidia & $119.4 \pm 23.6$ & $5.68 \pm 1.14^{\mathrm{a}}$ & $43.5 \pm 2.9^{a}$ & $35.0 \pm 2.4^{\mathrm{a}}$ & $63.7 \pm 17.8^{\mathrm{abc}}$ \\
\hline Trichantera & $103.1 \pm 12.2$ & $11.21 \pm 0.82^{c}$ & $62.9 \pm 1.8^{c}$ & $53.1 \pm 2.4^{c}$ & $80.7 \pm 10.7^{\text {defg }}$ \\
\hline Indigofera & $134.7 \pm 33.9$ & $12.28 \pm 3.23^{\mathrm{cd}}$ & $70.3 \pm 1.4^{\mathrm{d}}$ & $65.7 \pm 2.5^{\mathrm{d}}$ & $75.4 \pm 13.1^{\text {cdef }}$ \\
\hline Calliandra & $142.3 \pm 27.3$ & $8.71 \pm 0.27^{\mathrm{b}}$ & $46.0 \pm 0.9^{a}$ & $37.7 \pm 2.1^{\mathrm{ab}}$ & $69.3 \pm 14.4^{\mathrm{bcd}}$ \\
\hline Papaya leaf & $112.8 \pm 32.9$ & $11.96 \pm 2.74^{\mathrm{cd}}$ & $74.9 \pm 2.5^{\mathrm{e}}$ & $70.9 \pm 2.3^{e}$ & $80.1 \pm 13.4^{\text {defg }}$ \\
\hline Cassava leaf & $127.2 \pm 10.7$ & $9.38 \pm 1.78^{\mathrm{b}}$ & $57.1 \pm 1.9^{\mathrm{b}}$ & $51.7 \pm 2.0^{c}$ & $74.6 \pm 14.0^{\text {cde }}$ \\
\hline Leucaena & $128.9 \pm 28.4$ & $6.67 \pm 1.02^{\mathrm{a}}$ & $58.2 \pm 1.6^{b}$ & $39.4 \pm 2.4^{b}$ & $56.0 \pm 25.8^{\mathrm{ab}}$ \\
\hline \multicolumn{6}{|l|}{ Concentrate } \\
\hline Rapeseed meal & $116.5 \pm 10.4$ & $8.46 \pm 0.43^{b}$ & $77.1 \pm 1.0^{\text {ef }}$ & $71.3 \pm 2.0^{\mathrm{e}}$ & $89.4 \pm 5.9^{\mathrm{fg}}$ \\
\hline Corn gluten feed & $108.1 \pm 29.6$ & $5.88 \pm 1.37^{a}$ & $79.3 \pm 1.2^{\mathrm{fg}}$ & $77.6 \pm 1.5^{\mathrm{f}}$ & $72.8 \pm 12.2^{\text {cde }}$ \\
\hline Soybean meal & $121.2 \pm 12.1$ & $8.73 \pm 2.85^{\mathrm{b}}$ & $93.8 \pm 1.3^{\mathrm{h}}$ & $92.6 \pm 1.9 \mathrm{~g}$ & $92.2 \pm 1.9 \mathrm{~g}$ \\
\hline Copra meal & $120.9 \pm 47.3$ & $6.35 \pm 1.08^{a}$ & $80.4 \pm 1.7 \mathrm{~g}$ & $77.5 \pm 2.1^{\mathrm{f}}$ & $54.7 \pm 8.1^{\mathrm{a}}$ \\
\hline Palm kernel meal & $119.9 \pm 25.7$ & $6.74 \pm 1.92^{\mathrm{a}}$ & $75.8 \pm 1.8^{\mathrm{e}}$ & $74.6 \pm 1.4^{\mathrm{f}}$ & $74.0 \pm 9.8^{\text {cde }}$ \\
\hline Fish and bone meal & $115.8 \pm 11.2$ & $13.60 \pm 0.98^{\mathrm{d}}$ & $75.3 \pm 1.8^{\mathrm{e}}$ & $63.9 \pm 3.1^{\mathrm{d}}$ & $80.1 \pm 10.6^{\text {defg }}$ \\
\hline Wheat bran & $110.6 \pm 31.7$ & $8.79 \pm 1.01^{\mathrm{b}}$ & $71.2 \pm 4.4^{\mathrm{d}}$ & $65.5 \pm 5.3^{d}$ & $85.4 \pm 9.8^{\text {efg }}$ \\
\hline SEM & 3.720 & 0.320 & 1.498 & 1.918 & 2.376 \\
\hline P-value & 0.927 & $<0.001$ & $<0.001$ & $<0.001$ & $<0.001$ \\
\hline
\end{tabular}

Note: $\mathrm{VFA}=$ volatile fatty acid; $\mathrm{DMD}=$ dry matter digestibility; $\mathrm{OMD}=$ organic matter digestibility; $\mathrm{CPD}=$ crude protein digestibility .

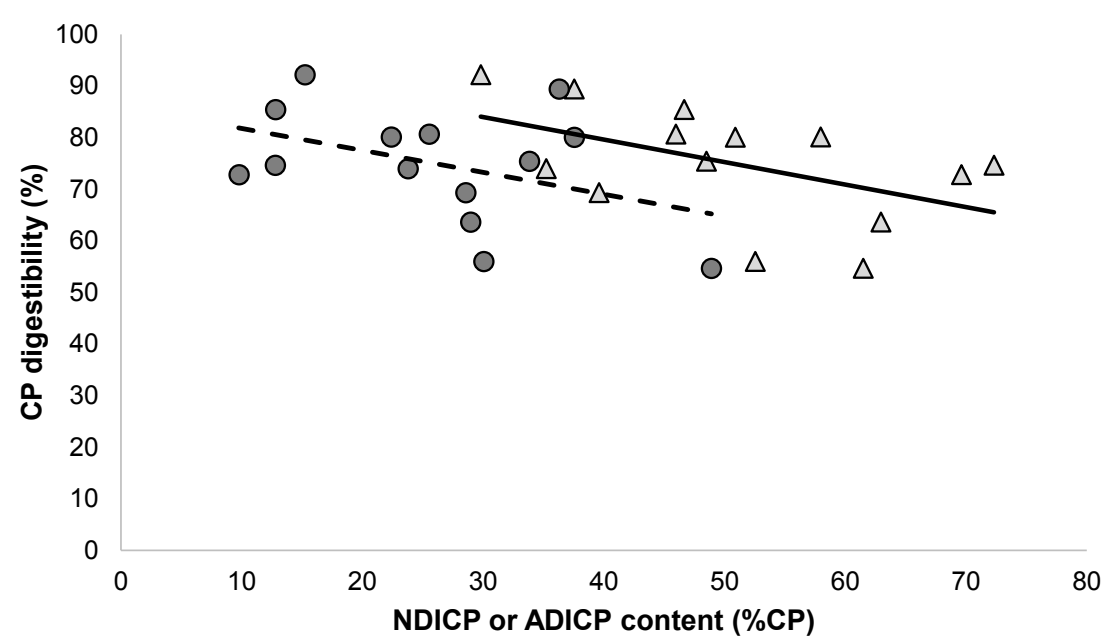

Figure 1. Relationship between NDICP (- $\left.\Delta^{-}\right)$or ADICP (-o-) content in selected feedstuffs and in vitro ruminal $\mathrm{CP}$ digestibility. CP digestibility= 97.0 - 0.436 NDICP $(n=14 ; r=0.502 ; P=0.067) ; C P$ digestibility= 86.0 - 0.424 ADICP $(n=14 ; r=0.420 ; P=0.135)$; $\mathrm{NDICP}=$ neutral detergent insoluble crude protein; $\mathrm{ADICP}=$ acid detergent insoluble crude protein; $\mathrm{CP}=$ crude protein.

ADICP apparently tended to decrease CP digestibility as well, the relationship was insignificant due to the higher variation of the dependent variable.

\section{DISCUSSION}

\section{Chemical Composition of Feedstuffs}

The high CP content of cassava leaf has been also reported in other studies. For instance, Jayanegara et al. (2013) reported that cassava leaf contained 38.6\% DM of CP which was higher than in the present experiment. Other authors reported lower $\mathrm{CP}$ values, i.e. ranged from 17.7-24.0\% DM (Oni et al., 2011; Hue et al., 2012).
Such high CP content of cassava leaf suggest that the material is a potential feedstuff to be used as a protein supplement. However, it has to be used with caution since the leaf contains cyanogenic glycosides that can be converted into hydrogen cyanide and, in turn, may cause toxic responses to the animals (Soto-Blanco \& Gorniak, 2010). A certain pre-treatment on fresh cassava leaf prior to feeding to animals may be needed to avoid toxicity responses. Another forage species that recently has become widely used as ruminant feed in Indonesia is indigofera. Apart from its high biomass production per unit of land, indigofera is relatively resistant to drought, contains high CP content (around 27\% DM) and highly digestible (Abdullah, 2010). The CP content 
obtained in this study was relatively similar to that was reported by Abdullah (2010). Other forages, i.e. gliricidia, trichantera, calliandra, papaya leaf and leucaena were also high in $\mathrm{CP}$ contents and therefore may be used as protein supplements in ruminant diets.

Soybean meal is the most well-known protein concentrate originated from plants due to its superiority in CP content and quality (Maxin et al., 2013) as was also proven in the present study. Other concentrate feedstuffs are still hard to compete with soybean meal due to their lower $\mathrm{CP}$ contents or the high presence of $\mathrm{CF}$ like in palm kernel meal and copra meal. The EE contents observed in palm kernel meal and copra meal were high, indicating inefficient oil extraction from the original materials. A study of Sulabo et al. (2013) reported that the EE contents of palm kernel meal and copra meal were $1.3 \%$ and $1.9 \%$ DM, respectively; these results were more than one-fourth lower compared to the results obtained in the present experiment. Such high EE may shorten the shelf-life of palm kernel meal and copra meal due to oxidation and rancidity processes during the storage. With regard to fish and bone meal that contained low $\mathrm{CP}$ and very high ash contents, the material was indeed different from common fish meal that typically contains over 60\% CP (Jelantik et al., 2012). The material used in this study apparently contained a high proportion of fish bone and thus contributed to the elevation of ash content, particularly from calcium and phosphorus.

To date, there has been no study attempting to analyze NDICP and ADICP contents of feedstuffs in Indonesia. Therefore, this study is an initiation for the analyses in the country. Compared to data in Vietnam (Tham et al., 2008), ADICP for cassava leaf in the present experiment was higher. Similarly, leucaena and gliricidia here were also higher than those reported by Tham et al. (2008). The ADICP is a protein fraction that insoluble in acid detergent and typically represents the protein associated with lignin and heat-damaged protein (Licitra et al., 1996; Pelletier et al., 2010). Therefore this fraction is considered to be undigestible in the digestive tract of ruminants. Higher proportion of ADICP over CP indicates that a low protein quality of a feedstuff. The NDICP is a protein fraction that insoluble in neutral detergent and it is considered to be slowly degraded or undegraded in the rumen. Since part of the NDICP is ADICP, subtraction of the latter to the former (NDICP - ADICP) may provide important information on the amount of rumen by-pass protein. This value, i.e. NDICP - ADICP is called as B3 fraction in the Cornell Net Carbohydrate and Protein System (CNCPS; Higgs et al., 2012). Apparently, NDICP and ADICP are valuable parameters to determine the quality of protein of a ruminant feedstuff and thus we recommend the analyses as routine procedures, apart from proximate and Van Soest's analyses, in animal nutrition (especially ruminant nutrition) related laboratories in Indonesia.

\section{In Vitro Rumen Fermentation and Digestibility}

The VFA is produced in the gastrointestinal tract, particularly in the rumen, through microbial fermenta- tion of carbohydrates, both structural and non-structural carbohydrates. This microbial fermentation product contributes largely, i.e., approximately $70 \%$ to the total energy requirement of ruminants, and such contribution becomes greater when the animals consume more proportion of fiber in their diets (Bergman, 1990). The range of VFA in the present experiment was within an optimal range for ruminants, i.e., between 80-160 $\mathrm{mM}$ (McDonald et al., 2011), indicating that all the experimental feedstuffs provide sufficient fermentable substrates for VFA production. Apart from its involvement as a major energy source of ruminants, VFA also plays a role as the building block for milk synthesis in dairy animals; acetate is a precursor for milk fat synthesis whereas propionate is a precursor for glucose and lactose productions (Aluwong et al., 2010). With regard to ammonia, ammonia concentrations obtained in this study were generally low, taking into consideration that all the experimental feedstuffs are rich in protein. Apparently this is due to the early sampling period, i.e. $4 \mathrm{~h}$ after incubation. Ammonia pool in the rumen is not an end-product metabolism; it is rather an intermediate product. Ammonia is primarily resulted from feed protein degradation and deamination, and may also be derived from microbial lysis or metabolism. The substance may loss from the rumen pool through incorporation into microbial cells, ammonia outflow from the rumen to the next digestive tract and absorption of ammonia through the rumen wall (Leng \& Nolan, 1984; Bach et al., 2005). Rumen microbial growth rate and mass achieve their peak at 3-6 $\mathrm{h}$ after feeding (Baldwin \& Denham, 1979). Therefore it is alleged that most of the ammonia is incorporated into microbial mass at $4 \mathrm{~h}$ after incubation, and this incorporation rate is much faster than its degradation rate from feed protein.

Superiority of papaya leaf on digestibility, both DMD and OMD in this study was in accordance with the study of Jayanegara et al. (2011). Among 27 tropical forage species reported by the authors, papaya leaf had the highest OMD, i.e. $82.5 \%$. Lower OMD of cassava leaf than that obtained by Jayanegara et al. (2011) was apparently due to the difference in plant material and stage of maturity when the leaf was harvested. Calliandra and leucaena had low DMD and OMD since the plants contain high amounts of tannins, i.e. $8.1 \%$ and $6.7 \%$ DM, respectively, although other plant secondary compounds such as saponins may contribute to the effects (Jayanegara et al., 2014). Such high amounts of tannins were shown to be negatively correlated with total gas production and OMD (Jayanegara et al., 2011) since the compounds bind to protein and fiber present in feedstuffs through particularly hydrogen bonds (Jayanegara et al., 2009; 2015). Similar explanation was also applied to gliricidia since the forage contains substantial amount of tannins (Cudjoe \& Mlambo, 2014; Rira et al., 2015). Soybean meal showed the highest DMD and OMD over all other feedstuffs, indicating its superiority as a plant based protein concentrate. Maxin et al. (2013) showed that soybean meal had a high proportion of water soluble and rapidly degradable DM fraction. Further, insoluble but degradable DM fraction of soybean meal was also shown to have a high degradation rate, i.e. $9 \%$ per 
h. In comparison with other plant based concentrates in which the typical degradation rate is around 5\% to $7 \%$ per $h$, soybean meal clearly shows a higher value.

Generally protein is highly digestible in the digestive tract of ruminants (Riaz et al., 2014) and this study confirmed such a theory. Relatively low CPD of gliricidia, calliandra and leaucaena was apparently, again, due to the presence of tannins at considerable amounts in these plants as described above. Actually, tannins may provide benefit when they protect protein from ruminal degradation and release the protein at abomasum under acidic environment. But when the protein remains bind together with the tannins in the lower digestive tract, on the contrary, tannins prevent protease to degrade the protein and thus lower its utilization. Since the two-stage in vitro technique already simulates the abomasum condition by addition of pepsin- $\mathrm{HCl}$ in the second stage (Tilley \& Terry, 1963), it seems that the later was the case for gliricidia, calliandra and leucaena. It is known that the type of tannins present in these forages are condensed tannins; the tannins are resistant to anaerobic degradation in the rumen (Jayanegara et al., 2011; 2013). Different from condensed tannins, another type of tannins, i.e. hydrolysable tannins are degraded in the digestive tract and thus may potentially promote the amount of rumen by-pass protein that available in the lower digestive tract.

The tendency of a negative relationship between NDICP or ADICP and CP digestibility may indicate the usefulness of cell wall protein as an indicator of protein utilization by ruminants. This analysis therefore is recommended to be performed as a routine analysis in animal nutrition laboratories in Indonesia. Its determination is relatively easy as well; it needs only an additional step to obtain the value, i.e. by analyzing CP (either by Kjeldahl or Dumas method) from the NDF or ADF residues of the feedstuffs. Subtracting ADICP value from $\mathrm{CP}$ may provide an indication of available protein for the animals. Ideally, available protein is determined by using rumen and duodenal cannulas; rumen degradable protein (RDP) and rumen undegradable protein (RUP) are quantified by considering the amount of soluble nitrogen and degradation rate of insoluble but degradable protein, and the availability of protein in the small intestine or known as metabolizable protein (MP) (Lee et al., 2012; Bahrami-Yekdangi et al., 2014). Since this technique is presently less developed in Indonesia, the cell wall protein content may serve as an alternative indicator for protein availability. However, it has to be noted that the presence of other components that interact with protein, such as tannins from some feedstuffs in the present study, may deviate the relationship between NDICP or ADICP with CP digestibility; this causes higher variation of the $\mathrm{CP}$ digestibility.

\section{CONCLUSION}

Among the experimental forages, cassava leaf had the highest proportion of NDICP while corn gluten feed was the highest among the concentrates. Different with that of NDICP, the highest proportion of ADICP was obtained in papaya leaf and copra meal for the forages and concentrates, respectively. Such cell wall protein in feed, i.e. NDICP or ADICP may be used as an indicator to determine the quality of protein and its utilization in the rumen and ruminants. This analysis is therefore recommended to be performed as a routine analysis in animal nutrition laboratories in Indonesia due to its usefulness and easy determination. Caution on the interpretation of result has to be taken into account in the presence of other components that interact with protein such as tannins.

\section{ACKNOWLEDGEMENT}

All authors are grateful to Indonesian Directorate General of Higher Education (DIKTI) for providing financial support to this research project.

\section{REFERENCES}

Abdullah, L. 2010. Herbage production and quality of shrub indigofera treated by different concentration of foliar fertilizer. Med. Pet. 33:169-175. http://dx.doi.org/10.5398/medpet.2010.33.3.169

AOAC. 2005. Official Methods of Analysis. $18^{\text {th }}$ Edition. AOAC International, Arlington, VA, USA.

Bach, A., S. Calsamiglia, \& M. D. Stern. 2005. Nitrogen metabolism in the rumen. J. Dairy Sci. 88 (E. Suppl.):E9-E21.

Bahrami-Yekdangi, H., M. Khorvash, G. R. Ghorbani, M. Alikhani, R. Jahanian, \& E. Kamalian. 2014. Effects of decreasing metabolizable protein and rumen-undegradable protein on milk production and composition and blood metabolites of Holstein dairy cows in early lactation. J. Dairy Sci. 97:3707-3714. http://dx.doi.org/10.3168/jds.20136725

Baldwin, R. L., \& S. C. Denham. 1979. Quantitative and dynamic aspects of nitrogen metabolism in the rumen: a modeling analysis. J. Anim. Sci. 49:1631-1639.

Bergman, E. N. 1990. Energy contributions of volatile fatty acids from the gastrointestinal tract in various species. Physiol. Rev. 70:567-590.

Cudjoe, N., \& V. Mlambo. 2014. Buffer nitrogen solubility, in vitro ruminal partitioning of nitrogen and in vitro ruminal biological activity of tannins in leaves of four fodder tree species. J. Anim. Physiol. Anim. Nutr. 98:722-730. http:// dx.doi.org/10.1111/jpn.12130

Das, L. K., S. S. Kundu, D. Kumar, \& C. Datt. 2014. The evaluation of metabolizable protein content of some indigenous feedstuffs used in ruminant nutrition. Vet. World 7:257261. http://dx.doi.org/10.14202/vetworld.2014.257-261

Das, L. K., S. S. Kundu, D. Kumar, \& C. Datt. 2015. Fractionation of carbohydrate and protein content of some forage feeds of ruminants for nutritive evaluation. Vet. World 8:197202. http://dx.doi.org/10.14202/vetworld.2015.197-202

Edmunds, B., K. H. Sudekum, H. Spiekers, \& F. J. Schwarz. 2012. Estimating ruminal crude protein degradation using in situ and in vitro techniques. Anim. Feed Sci. Technol. 175:95-105. http://dx.doi.org/10.1016/j.anifeedsci.2012.04.003

General Laboratory Procedures. 1966. Department of Dairy Science, University of Wisconsin, Madison, USA.

Higgs, R. J., L. E. Chase, \& M. E. Van Amburgh. 2012. Development and evaluation of equations in the Cornell Net Carbohydrate and Protein System to predict nitrogen excretion in lactating dairy cows. J. Dairy Sci. 95:2004-2014. http://dx.doi.org/10.3168/jds.2011-4810

Hue, K. T., D. T. T. Van, E. Sporndly, I. Ledin, \& E. Wredle. 2012. Effect of adaptation strategies when feeding fresh 
cassava foliage on intake and physiological responses of lambs. Trop. Anim. Health Prod. 44:267-276. http://dx.doi. org/10.1007/s11250-011-0013-0

Jayanegara, A., H. P. S. Makkar, \& K. Becker. 2009. Emisi metana dan fermentasi rumen in vitro ransum hay yang mengandung tanin murni pada konsentrasi rendah. Med. Pet. 32:184-194.

Jayanegara, A., E. Wina, C. R. Soliva, S. Marquardt, M. Kreuzer, \& F. Leiber. 2011. Dependence of forage quality and methanogenic potential of tropical plants on their phenolic fractions as determined by principal component analysis. Anim. Feed Sci. Technol. 163:231-243. http://dx.doi. org/10.1016/j.anifeedsci.2010.11.009

Jayanegara, A., S. Marquardt, E. Wina, M. Kreuzer, \& F. Leiber. 2013. In vitro indications for favourable non-additive effects on ruminal methane mitigation between high-phenolic and high-quality forages. Brit. J. Nutr. 109:615-622. http://dx.doi.org/10.1017/S0007114512001742

Jayanegara, A., E. Wina, \& J. Takahashi. 2014. Meta-analysis on methane mitigating properties of saponin-rich sources in the rumen: influence of addition levels and plant sources. Asian Australas. J. Anim. Sci. 27:1426-1435. http://dx.doi. org/10.5713/ajas.2014.14086

Jayanegara, A., G. Goel, H. P. S. Makkar, \& K. Becker. 2015. Divergence between purified hydrolysable and condensed tannin effects on methane emission, rumen fermentation and microbial population in vitro. Anim. Feed Sci. Technol. 209:60-68. http://dx.doi.org/10.1016/j.anifeedsci.2015.08.002

Jelantik, I. G. N., M. R. Weisbjerg, \& J. Madsen. 2012. Intake, rumen degradation and utilisation of urea-ammoniated grass hay by Kacang goats as affected by supplementation of sun-dried fish or fish meal. Anim. Prod. 14:77-86.

Khan, N. A., Q. Peng, H. Xin, \& P. Yu. 2015. Vibrational spectroscopic investigation of heat-induced changes in functional groups related to protein structural conformation in camelina seeds and their relationship to digestion in dairy cows. Anim. Prod. Sci. 55:201-206. http://dx.doi. org/10.1071/AN14400

Lee, C., A. N. Hristov, K. S. Heyler, T. W. Cassidy, H. Lapierre, G. A. Varga, \& C. Parys. 2012. Effects of metabolizable protein supply and amino acid supplementation on nitrogen utilization, milk production, and ammonia emissions from manure in dairy cows. J. Dairy Sci. 95:5253-5268. http:// dx.doi.org/10.3168/jds.2012-5366

Leng, R. A., \& J. V. Nolan. 1984. Nitrogen metabolism in the rumen. J. Dairy Sci. 67:1072-1089. http://dx.doi.org/10.3168/ jds.S0022-0302(84)81409-5

Licitra, G., T. M. Hernandez, \& P. J. Van Soest. 1996. Standardization of procedures for nitrogen fractionation of ruminant feeds. Anim. Feed Sci. Technol. 57:347-358. http:// dx.doi.org/10.1016/0377-8401(95)00837-3

Maxin, G., D. R. Ouellet, \& H. Lapierre. 2013. Ruminal degradability of dry matter, crude protein, and amino acids in soybean meal, canola meal, and wheat dried distillers grains. J. Dairy Sci. 96:5151-5160. http://dx.doi.org/10.3168/ jds.2012-6392
McDonald, P., R. A. Edwards, J. F. D. Greenhalgh, C. A. Morgan, L. A. Sinclair, \& R. G. Wilkinson. 2011. Animal Nutrition. 7th Ed. Prentice Hall, Harlow, England.

Oni, A. O., C. F. I. Onwuka, O. M. Arigbede, U. Y. Anele, O. O. Oduguwa, O. S. Onifade, \& Z. L. Tan. 2011. Chemical composition and nutritive value of four varieties of cassava leaves grown in South-Western Nigeria. J. Anim. Physiol. Anim. Nutr. 95:583-590. http://dx.doi.org/10.1111/j.14390396.2010.01086.x

Pelletier, S., G. F. Tremblay, A. Bertrand, G. Belanger, Y. Castonguay, \& R. Michaud. 2010. Drying procedures affect non-structural carbohydrates and other nutritive value attributes in forage samples. Anim. Feed Sci. Technol. 157:139-150. http://dx.doi.org/10.1016/j.anifeedsci.2010.02.010

Riaz, M. Q., K. H. Sudekum, M. Clauss, \& A. Jayanegara. 2014. Voluntary feed intake and digestibility of four domestic ruminant species as influenced by dietary constituents: A meta-analysis. Livest. Sci. 162:76-85. http://dx.doi. org/10.1016/j.livsci.2014.01.009

Rira, M., D. P. Morgavi, H. Archimede, C. Marie-Magdeleine, M. Popova, H. Bousseboua, \& M. Doreau. 2015. Potential of tannin-rich plants for modulating ruminal microbes and ruminal fermentation in sheep. J. Anim. Sci. 93:334-347. http://dx.doi.org/10.2527/jas.2014-7961

Saez-Plaza, P., T. Michalowski, M. J. Navas, A. G. Asuero, \& S. Wybraniec. 2013. An overview of the Kjeldahl method of nitrogen determination. Part I. Early history, chemistry of the procedure, and titrimetric finish. Crit. Rev. Anal. Chem. 43:178-223. http://dx.doi.org/10.1080/10408347.201 2.751786

Soto-Blanco, B., \& S. L. Gorniak. 2010. Toxic effects of prolonged administration of leaves of cassava (Manihot esculenta Crantz) to goats. Exp. Toxicol. Pathol. 62:361-366. http://dx.doi.org/10.1016/j.etp.2009.05.011

Sulabo, R. C., W. S. Ju, \& H. H. Stein. 2013. Amino acid digestibility and concentration of digestible and metabolizable energy in copra meal, palm kernel expellers, and palm kernel meal fed to growing pigs. J. Anim. Sci. 91:1391-1399. http://dx.doi.org/10.2527/jas.2012-5281

Tan, L., S. Eberhard, S. Pattathil, C. Warder, J. Glushka, C. Yuan, Z. Hao, X. Zhu, U. Avci, J. S. Miller, D. Baldwin, C. Pham, R. Orlando, A. Darvill, M. G. Hahn, M. J. Kieliszewski, \& D. Mohnen. 2013. An Arabidopsis cell wall proteoglycan consists of pectin and arabinoxylan covalently linked to an arabinogalactan protein. Plant Cell 25:270-287. http://dx.doi.org/10.1105/tpc.112.107334

Tham, H. T., N. V. Man, \& T. R. Preston. 2008. Estimates of protein fractions of various-heat treated feeds in ruminant production. Livest. Res. Rur. Dev. 20 (suppl.). http://www. lrrd.org/lrrd20/supplement/tham2.htm [14 June 2015].

Tilley, J. M. A., \& R. A. Terry. 1963. A two-stage technique for the in vitro digestion of forage crops. Grass Forage Sci. 18:104-111. http://dx.doi.org/10.1111/j.1365-2494.1963. tb00335.x

Van Soest, P. J., J. B. Robertson, \& B. A. Lewis. 1991. Methods for dietary fiber, neutral detergent fiber, and nonstarch polysaccharides in relation to animal nutrition. J. Dairy Sci. 74:3583-3597. http://dx.doi.org/10.3168/jds.S00220302(91)78551-2 